\title{
Litteraturen og revolutionen
}

Bolsjevikkernes sejr i borgerkrigen mod det gamle regimes støtter i 1920 markerede afslutningen på Den russiske revolution og indledningen på et årti, der ikke alene var kendetegnet af enorme politiske og sociale forandringer, men også af en eksplosion af kreativ energi. Ud fra ideen om, at en ny samfundsorden kræver en ny kunst, støttede stærke kræfter $i$ det nye kommuniststyre avantgardistiske bevægelser på alle områder af det kunstneriske liv. Inden for malerkunst og arkitektur slog konstruktivismen med blandt andre El Lisitskij, Vladimir Tatlin og Aleksandr Rodtjenko igennem, alt imens Sergej Eisenstein og Dziga Vertov revolutionerede filmkunsten, Vsevolod Meyerhold teatret og Vladimir Majakovskij poesien.

Lev Trotskij, en af revolutionens ledende skikkelser og øverstkommanderende for Den røde hær i borgerkrigen, bidrog aktivt til årtiets livlige debat om forholdet mellem en ny samfundsform og en ny kunst. Det skete ikke mindst gennem udgivelsen af Litteraturen og revolutionen $i$ 1923, der fordrer en forening af poetisk eksperiment og politisk engagement. I modsætning til futuristernes idé om et fuldstændigt brud med fortiden indebærer denne fordring for Trotskij ikke en afsked med det 19. århundredes såkaldt borgerlige litteratur, men en levende, historisk bevidst dialog. Såvel det kunstneriske eksperiment som den levende dialog kom imidlertid under pres i takt med Stalins stigende kontrol over kommunistpartiet og kulturen i slutningen af 1920'erne. Trotskij måtte drage i eksil i 1928, og et af de mest originale og produktive årtier i russisk kulturhistorie fik kort efter sin symbolske afslutning, da Stalin i 1932 erklærede den socialistiske realisme for officiel sovjetisk kunstdoktrin.

\section{Forord}

Kunstens plads kan bestemmes gennem følgende skematiske ræsonnement.

Hvis ikke det sejrende proletariat havde skabt sin egen hær, ville arbejderregeringen for længst være afgået ved døden, og vi ville ikke have haft anledning til nu at overveje økonomiske eller, så meget desto mindre, idé- og kulturmæssige problemer. 
Hvis diktaturet skulle vise sig ude af stand til i løbet af de nærmeste år at organisere en $\varnothing$ konomi, der sikrer befolkningen i det mindste et eksistensminimum af materielle goder, så vil proletarregimet uvægerligt gå i opløsning. Økonomien er lige nu den primære opgave.

Men selv en vellykket løsning af de grundlæggende problemer med fødevarer, klæder, opvarmning og endda læse- og skrivefærdigheder, hvilket ville være en stor samfundsmæssig bedrift, ville ikke under nogen omstændigheder kunne kaldes en fuld sejr for socialismen som nyt historisk princip. Kun en fortsat fremdrift, på fællesfolkeligt grundlag, inden for den videnskabelige tænkning samt udviklingen af en ny kunst vil være tegn på, at det historiske frø ikke blot er vokset til en stilk, men også har sat blomster. I den forstand er kunstens udvikling den ultimative prøve på enhver epokes levedygtighed og betydning.

Kulturen næres af økonomiens safter, og der skal være et materielt overskud, for at kulturen kan vokse, differentieres og raffineres. Vores borgerskab underlagde sig litteraturen, og det meget hurtigt, i den periode hvor denne stands rigdom øgedes sikkert og stærkt. Proletariatet vil kunne lægge grunden til skabelsen af en ny, dvs. socialistisk, kultur og litteratur, ikke på laboratorievis, på grundlag af vores nutidige fattigdom, mangler og analfabetisme, men derimod ad brede sociale, økonomiske og kulturaktivistiske veje. Kunstens eksistens er betinget af velstand, af overskud. Den er betinget af, at højovnene brænder kraftigere, at hjulene drejer hurtigere, at væveskytlerne glider kvikkere, at skolerne arbejder bedre.

Vores gamle litteratur og "kultur" var adelig og bureaukratisk, baseret på bondens arbejdskraft. Den selvsikre adelsmand og den skyldbetyngede adelsmand satte begge deres præg på den russiske litteraturs vigtigste periode. Siden dukkede den intellektuelle op, baseret på bonden og småborgeren, og indføjede sit kapitel i den russiske litteraturs historie. Efter at være gået igennem narodnik-bevægelsens forsøg på at leve folkets simple liv, blev den intellektuelle moderne, speciel, individuel i borgerlig forstand. Heri ligger dekadencens og symbolismens historiske rolle. Helt fra århundredets begyndelse, men især fra 1907-8, var intelligentsiaens borgerlige genfødsel i gang for fuld damp. Krigen gjorde, at denne proces fuldendtes i patriotismens tegn.

Revolutionen omstyrter borgerskabet, og dette afgørende faktum trænger ind i litteraturen. Den litteratur, der udkrystalliserede sig rundt om borgerstandens akse, falder nu fra hinanden. Hvad der er tilbage af liv på åndsarbejdets og særligt litteraturens område, forsøgte og forsøger stadig at nyorientere sig. Efter at borgerskabet er blevet fortid, er omdrejningspunktet for denne nyorientering folket minus borgerskabet. Men hvad vil det sige? Det vil først og fremmest sige bondestanden, til dels småborgerskabet i byerne, og først derefter arbejderne, eftersom de endnu ikke kan udskilles fra det bondefolkelige protoplasma. Denne grundindstilling har alle revolutionens medløbere. Fra den afdøde Blok til dem, der stadig lever i bedste velgående: Pilnjak, Serapion-brødrene, imaginisterne. Det gælder også en del af futuristerne (Khlebnikov, Krutjonykh, V. Kamenskij). Det at vores kultur - eller rettere mangel på samme - er baseret på bønder, viser sig her i al sin passive magt.

Vores revolution, det er bonden, som efter at være blevet proletar stadig støtter sig på bonden og viser vejen frem. Vores kunst, det er den intellektuelle, som 


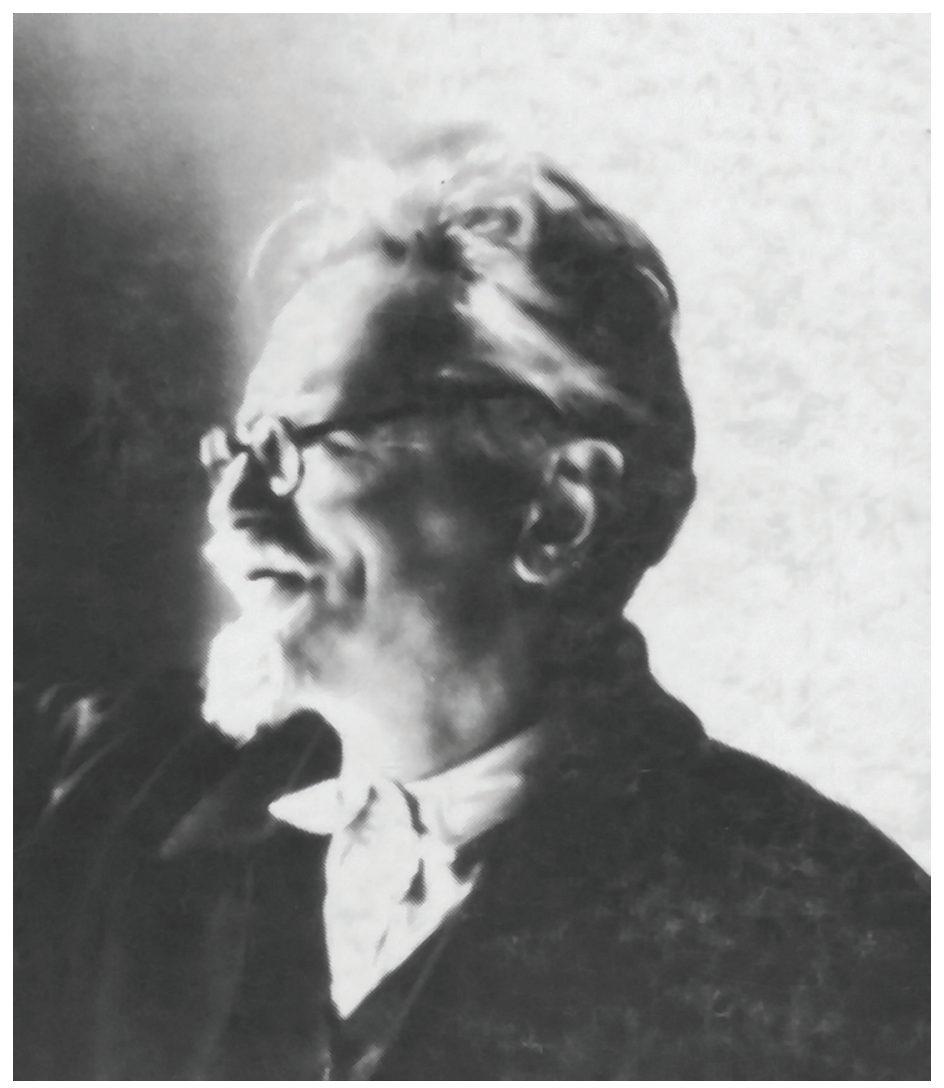

vakler mellem bonden og proletaren uden at kunne smelte organisk sammen med hverken den ene eller den anden, men som på grund af sin mellemposition og sine forbindelser hælder mest mod bonden: Blive bonde kan han ikke, men han kan sympatisere med bonden. Imidlertid kan der ikke være nogen revolution uden arbejderen som anfører. Det er dette, der skaber den grundlæggende modsætning i selve tilgangen til emnet. Man kan endda sige, at digterne og forfatterne i disse omvæltningsår fortrinsvis adskiller sig fra hinanden ved måden, hvorpå de kæmper sig ud af modsætningen, og hvad de fylder det efterladte hul ud med: En fylder det ud med mysticisme, en anden med romantik, en tredje med forsigtig undvigelse, en fjerde med et altoverdøvende skrig. Uagtet alle disse forskellige måder at overvinde modsætningen på, forbliver dens væsen det samme: Det borgerlige samfunds adskillelse af det åndelige arbejde, herunder kunsten, fra det fysiske, modstillet det faktum at revolutionen blev gennemført af fysisk arbejdende folk. Et af revolutionens endemål er den fulde overvindelse af opsplitningen mellem disse to former for aktivitet. I den forstand, som i enhver øvrig, ligger opgaven med at skabe en ny kunst helt på linje med de grundlæggende opgaver i opbygningen af en socialistisk kultur.

Det er latterligt, absurd, virkelig ekstremt dumt at lade, som om kunsten kan 
forblive upåvirket af den nuværende epokes rystelser. Der er tale om begivenheder, der iværksættes af mennesker, gennemføres af mennesker, ramler ned over dem og forandrer dem. Kunsten afspejler direkte og indirekte livet hos mennesker, som enten skaber eller gennemlever disse begivenheder. Det gælder al kunst, både den allermest monumentale og den helt intime. Hvis ikke naturen, kærligheden og venskabet var forbundne med en epokes sociale stemning, ville den lyriske digtning for længst være ophørt med at eksistere. Men et voldsomt brud i historien, dvs. en omgruppering af samfundsklasserne, rusker op i individet, etablerer en ny vinkel i det lyriske perspektiv på poesiens grundlæggende temaer og redder dermed kunsten fra evigt at gentage sig selv.

Men virker en epokes "ånd" da ikke usynligt og uafhængigt af den subjektive vilje? Det er svært at forklare... Selvfølgelig afspejler den sig i sidste ende hos alle. Både hos dem der accepterer den og personificerer den, og hos dem der kæmper forgæves imod, samt hos dem der passivt forsøger at gemme sig for den. Men dem, der passivt gemmer sig, er lige så stille i færd med at dø bort. Og dem, der kæmper imod, er højst i stand til at genoplive den gamle kunst fra en enkelt falmet glød eller to. Den nye kunst, som flytter grænser og lader kreativiteten brede sig, kan imidlertid kun skabes af dem, der lever i pagt med deres tid. Hvis man trækker en linje fra i dag til fremtidens socialistiske kunst, så er det tydeligt, at vi kun lige har taget hul på de indledende forberedelser.

Skematisk optegnet er grupperingerne i vores nuværende litteratur som følger:

Den ikke-revolutionære litteratur, fra Suvorins feuilleton-forfattere til de sarteste af lyrikerne i godsejernes golde dal, er i færd med at dø bort sammen med de klasser, den har tjent. Formmæssigt og genealogisk set afslutter denne litteratur den ældste linje i vores gamle litteratur, som i begyndelsen var adelig, men endte med at være helt igennem borgerlig.

Den "sovjetiske", bondesympatiserende litteratur kan formmæssigt, om end knap så indiskutabelt, føres tilbage til den gamle litteraturs slavofile og narodnikprægede strømninger. Selvfølgelig udgår bondesympatisørerne heller ikke direkte fra bonden. De ville være utænkelige uden den forudgående adelige og borgerlige litteratur, hvis seneste udvikling de repræsenterer. Og de er nu i gang med at omstille sig til den nye sociale situation.

Også futurismen er indiskutabelt en udløber af den gamle litteratur. Men den russiske futurisme nåede ikke at udfolde sig inden for den gamle litteraturs rammer, den gennemgik ikke den uomgængelige borgerlige genfødsel, der kunne føre til officiel anerkendelse. Da krigen og revolutionen brød ud, befandt den sig således stadig på det boheme-stadie, som er normalt for enhver ny litteraturstrømning under den urbane kapitalismes vilkår. Tilskyndet af begivenhederne styrede futurismen sin udvikling i den nye, revolutionære retning. Det kom der ikke, og kunne der i sagens natur ikke komme proletarkunst ud af. Men skønt futurismen i mangt og meget forbliver en boheme-revolutionær udløber af den gamle kunst, indgår den dog tættere, mere direkte og mere aktivt end andre retninger i udformningen af en ny kunst.

Uanset hvor betydelige enkeltstående proletardigteres frembringelser måtte være, så er den såkaldte "proletarkunst" overordnet set kun i gang med sine læreår. 


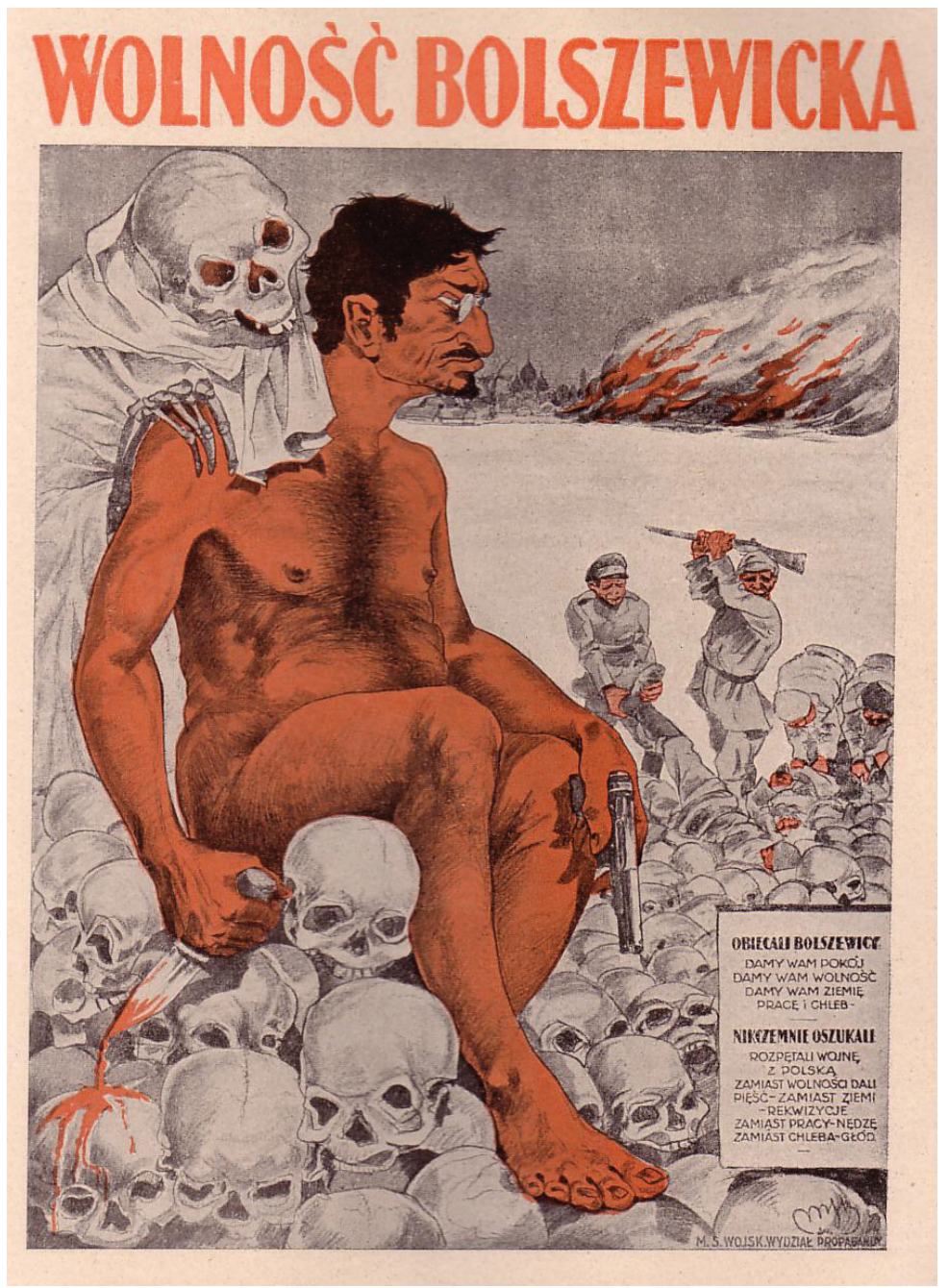

"Bolsjevikisk frihed" Antikommunistisk plakat produceret af den polske regering under den polsk-russiske krig 1920. Viser Folkets Kommissær for den Røde Hær, Lev Trotskij.

Den spreder den kunstneriske kulturs frø vidt omkring, hjælper en ny klasse, som endnu har form af et yderst tyndt samfundslag, med at tilegne sig tidligere tiders frembringelser og udgør i den forstand en af kilderne til fremtidens socialistiske kunst.

Det er grundlæggende forkert at modstille den borgerlige kultur og kunst med proletarkultur og proletarkunst. De sidstnævnte vil aldrig findes, eftersom det proletariske regime er en midlertidig overgangsfase. Den proletariske revolutions historiske betydning og moralske storslåethed består i, at den bereder grunden for en klasseløs kultur, den første ægte menneskelige kultur.

Vores kunstpolitik i denne overgangsperiode kan og bør være rettet mod at hjælpe de forskellige kunstneriske grupperinger og strømninger, som har stillet sig på revolutionens side, med at opnå den rette forståelse af dens historiske 
betydning. Efter at have stillet alle over for det kategoriske kriterium, at de enten er for revolutionen eller imod revolutionen, skal vi give dem fuld frihed til kunstnerisk selvbestemmelse.

Revolutionen vil finde sin afspejling i kunsten - foreløbig er det sket i begrænset omfang - efterhånden som kunstnerne ophører med at se den som en ydre katastrofe, og efterhånden som digtere og kunstnere, nye som gamle, som gruppe vokser sammen med revolutionens levende væv og lærer at se den indefra i stedet for udefra.

Den sociale hvirvelstrøm vil ikke lægge sig lige med det samme. I Europa og Amerika forestår årtiers kamp. Kampen vil ikke kun have folk af vores generation men også af den kommende som sine deltagere, helte og ofre. Denne epokes kunst vil stå fuldt og helt i revolutionens tegn. Den har brug for en ny slags bevidsthed. Først og fremmest er den uforenelig med mysticisme, både af den åbne slags og den der har forklædt sig som romantik, for revolutionen baserer sig på den grundidé, at det kollektive menneske bør være den eneste herre, og at grænserne for hans magt alene defineres af hans kendskab til naturkræfterne og hans evne til at udnytte dem. Denne epokes kunst er uforenelig med pessimisme, skepsis og alle andre afarter af åndelig opgivenhed. Den er realistisk, aktiv, opfyldt af ægte kollektivisme og af en grænseløs, skabende tro på fremtiden...

L. Trotskij

19. september, 1923.

Oprindeligt fra Literatura i revoljutsija, Moskva: Krasnaja nov, 1923

Oversat af Tine Roesen 